\title{
Overview of E-Cigarette (Vape) Usage Behavior in 2021 UMJ FKM Students
}

\author{
${ }^{1}$ Ega Oktavia, ${ }^{2}$ Alika Fitri Azizah, ${ }^{3}$ Baby Shafira Zaintira, ${ }^{4}$ Carlina Surya \\ Faculty of Public Health, Muhammadiyah University of Jakarta \\ K.H. Ahmad Dahlan St, Cireundeu, Ciputat, South Tangerang, 15419 \\ E-mail: viaoktaega2@gmail.com
}

\begin{abstract}
E-cigarettes were first created in a modern way by a pharmacist from China in 2003 and patented in 2004 and then began to spread throughout the world. The results of a survey conducted by the International Tobacco Control Survey in America, Canada, Australia, and England, currently 29\% of former smokers use electronic cigarettes, $7.6 \%$ have tried using electronic cigarettes and $46.6 \%$ are aware of the existence of electronic cigarettes. Some conditions that can arise from long-term use of nicotine are increased blood pressure and heart rate, as well as an increased risk of developing insulin resistance, type 2 diabetes, and heart disease. This research uses a qualitative approach with a descriptive method. Based on in-depth interviews with the informants, it was found that the informants had various reasons for using vapor, both for health reasons and for environmental reasons. All resource persons also argue that the dominant factor that makes a person use vapor is environmental factors. Meanwhile, when viewed from the behavior of all informants, they do not use vapor continuously but at certain times, even one of the informants still uses conventional cigarettes to be accompanied by vapor.
\end{abstract}

Keywords: Electronic Cigarettes, Behavior, Students of FKM UMJ 
E-ISSN: 2808-5361 http://e-journal.fkmumj.ac.id/
Proceeding The First

Muhammadiyah Internasional-

Public Health and Medicine

Conference

\section{INTRODUCTION}

E-cigarettes were first created in a modern way by a pharmacist from China in 2003 and patented in 2004 and then began to spread throughout the world in 2006-until now with various brands (Caponetto, et al. 2014). E-cigarettes are becoming a trend in Indonesia, which is getting more and more fans. Ecigarettes can be very easy to find because sellers sell them through online sales with various flavors and variations in design (BPOM, 2015).

The results of a survey conducted by the International Tobacco Control Survey in America, Canada, Australia, and England, currently $29 \%$ of former smokers use electronic cigarettes, $7.6 \%$ have tried using electronic cigarettes and $46.6 \%$ are aware of the existence of electronic cigarettes. In the UK, there were an estimated 600,000 e-cigarette users in 2012, which has more than doubled from $2.7 \%$ of the population in 2010 to $6.7 \%$ in 2012 (Dockrell et al., 2013).

In Indonesia, the use of e-cigarettes is still a lot and is increasingly mushrooming. Until now, researchers have not obtained definite data on how many users of e-cigarettes in Indonesia, but Riskesdas (2013) surveyed a total of adolescents found $2.1 \%$ of adolescents smoked e-cigarettes (vaporizers) during the last 30 days, and this happened in the last 30 days. $3 \%$ of boys and $1.1 \%$ of girls (Kemenkes RI, 2013).Some conditions that can arise from long-term use of nicotine are increased blood pressure and heart rate, as well as an increased risk of developing insulin resistance, type 2 diabetes, and heart disease. Lifestyle, curiosity, wanting to quit conventional cigarettes and being consumed by the myth that e-cigarettes are less harmful than conventional cigarettes are some of the reasons and motivations for someone to smoke e-cigarettes. Based on the above phenomenon, the researcher is interested in taking the title "Description of the Behavior of Using E-Cigarettes (Vape) in FKM UMJ 2021 Students".

\section{METHODS}

This study uses a qualitative approach with a descriptive method. This was done to obtain more in-depth information about the description of the behavior of using e-cigarettes (vape) in FKM UMJ 2021 students.

\section{RESULTS AND DISCUSSION}

An E-cigarette is a device that functions like a cigarette but does not use or burn tobacco leaves, but converts liquid into vapor which is inhaled by smokers into their lungs, electronic cigarettes generally contain nicotine, other chemicals, and flavors/flavors and are toxic/toxic. poison (P2PTM). The Ministry of Health of the Republic of Indonesia (2014) explained that Electronic Cigarettes (ECs) or Electronic Nicotine Delivery System (ENDS) are devices that function to convert chemical substances into vapor and flow them to the lungs, where these chemicals are a mixture of substances such as nicotine and alcohol. propylene glycol (Karuniawati, 2019). 
Below are the results of the interviews which are displayed in the form of a matrix. Because the author keeps the name of the source a secret, the author will only describe the identity of the source. Our resource persons consist of 4 people who are active students of the Faculty of Public Health. The age range of the informants is $20-22$ years. Male and have been using vape for more than a month.

Table 1. Interview Matrix from Respondent 1

\begin{tabular}{|c|c|c|}
\hline Question & Answer & Conclusion \\
\hline \multicolumn{3}{|c|}{ Knowledge } \\
\hline $\begin{array}{l}\text { What Do the } \\
\text { benefits that you get } \\
\text { when using a vapor? }\end{array}$ & Feel more relaxed & $\begin{array}{l}\text { The benefits felt by } \\
\text { sources from using vaping } \\
\text { are feeling more } \\
\text { relaxed }\end{array}$ \\
\hline $\begin{array}{l}\text { Is there a difference } \\
\text { that you feel before } \\
\text { and after using } \\
\text { vape? }\end{array}$ & $\begin{array}{l}\text { There is a diversion of stress and burden of } \\
\text { mind after using vapor }\end{array}$ & $\begin{array}{l}\text { The informant felt the } \\
\text { the difference before and } \\
\text { after using a vape. The } \\
\text { resource person } \\
\text { becomes calmer because } \\
\text { vaping is used as a } \\
\text { diversion of stress and } \\
\text { burdens of the mind }\end{array}$ \\
\hline $\begin{array}{l}\text { Are you using } \\
\text { a liquid-vapor w hich } \\
\text { contained the-content } \\
\text { of nicotine? }\end{array}$ & Yes. & $\begin{array}{l}\text { The resource person } \\
\text { uses a liquid vape that } \\
\text { contains nicotine }\end{array}$ \\
\hline
\end{tabular}

Is there any impact that you know if using $\mathrm{g}$ a vapor? If so, what are the impacts?

How does the the way you avoid the impact of using a vapor?
Yes, some vascular and respiratory diseases Exercise regularly and avoid continuously vaping
Resource persons know the effects and diseases that can occur if using vape

\begin{tabular}{|c|c|c|}
\hline \multicolumn{3}{|c|}{ Attitude } \\
\hline $\begin{array}{l}\text { How } \\
\text { to view you as to } \\
\text { students of } \\
\text { Public } \\
\text { Health that uses } \\
\text { vapor? }\end{array}$ & $\begin{array}{l}\text { It's normal because they're quite mature } \\
\text { (it's legal to vote) and I'm sure they'll already } \\
\text { know the impact. }\end{array}$ & $\begin{array}{l}\text { The informant argued } \\
\text { that the use of vaping is } \\
\text { reasonable as long as } \\
\text { they are old enough and } \\
\text { know the impact }\end{array}$ \\
\hline $\begin{array}{l}\text { What do you } \\
\text { think about } \\
\text { "vapor is s a fe } \mathrm{r} \\
\text { than conventional } \\
1 \text { cigarettes"? }\end{array}$ & $\begin{array}{l}\text { Agree on several points but other points } \\
\text { also many say that vaping has a different impact }\end{array}$ & $\begin{array}{l}\text { The informants agreed } \\
\text { that vaping is safer than } \\
\text { conventional cigarettes } \\
\text { but has a different } \\
\text { impact }\end{array}$ \\
\hline
\end{tabular}




\begin{tabular}{|c|c|c|}
\hline $\begin{array}{l}\text { How } \\
\text { do think you abo } \\
\text { ut the "vapor one of } \\
\text { the tools to quit } \\
\text { smoking"? }\end{array}$ & $\begin{array}{l}\text { Agreed, because at first vaping was created } \\
\text { to replace cigarettes which have poisoned } \\
\text { humans a lot. Public Health of the United } \\
\text { Kingdom has also voiced "stop smoking, start } \\
\text { vaping" in the corners of the city of England. }\end{array}$ & $\begin{array}{l}\text { Narrators agree that } \\
\text { vapor is one of the tools } \\
\text { to quit smoking }\end{array}$ \\
\hline \multicolumn{3}{|c|}{ Personal References } \\
\hline $\begin{array}{l}\text { Has someone } \\
\text { influenced you to use } \\
\text { vape? }\end{array}$ & no & $\begin{array}{l}\text { The resource person is } \\
\text { not influenced by anyone } \\
\text { in using vape }\end{array}$ \\
\hline $\begin{array}{l}\text { In your opinion, } \\
\text { what is the most } \\
\text { dominant factor to } \\
\text { be the reason }\end{array}$ & $\begin{array}{l}\text { Stress relief, and the environment. I refuse } \\
\text { to smoke but because my environment is a smoker, } \\
\text { I choose to vape to divert my } \\
\text { desire to try cigarettes. }\end{array}$ & $\begin{array}{l}\text { The most dominant } \\
\text { factor in the use of } \\
\text { vaping is the } \\
\text { environment }\end{array}$ \\
\hline $\begin{array}{l}\text { Do you use } \\
\text { vapor? Tell! }\end{array}$ & & \\
\hline
\end{tabular}

\begin{tabular}{ll}
\hline & \multicolumn{1}{c}{ Action } \\
$\begin{array}{l}\text { Are you completely on } \\
\text { the vapor? }\end{array}$ & $\begin{array}{l}\text { The resource person is a } \\
\text { complete vapor }\end{array}$ \\
\hline $\begin{array}{l}\text { When } \\
\text { did you first start using } \\
\text { vape? }\end{array}$ & $\begin{array}{l}\text { The resource person has } \\
\text { been using vaping since } \\
\text { the 2nd grade of junior high } \\
\text { school }\end{array}$ \\
\hline
\end{tabular}

Time and place to use vape every day ? ?
Everywhere

Resource persons use vape anywhere
How

many times do you buy

vape liquid every month?
In one month, the interviewee purchases a liquid vape once a month
Where usually do purchase the fluid vapor and the means of vapor that is used?

What that be the reason you use vapor?
A trusted and safe vape shop (approved by the APVI institution).
Resource persons buy vape liquids at trusted and safe stores

Table 2. Interview Matrix from Respondent 2

\begin{tabular}{|c|c|c|}
\hline Question & Answer & Conclusion \\
\hline \multicolumn{3}{|c|}{ Knowledge } \\
\hline $\begin{array}{l}\text { What Do the } \\
\text { benefits that you get } \\
\text { when using a vapor? }\end{array}$ & $\begin{array}{l}\text { benefits of vaping } \\
\text { - no smell for the room or body like } \\
\text { cigarettes } \\
\text {-there is a taste } \\
\text {-don't make your hands yellow like a } \\
\text { cigarette } \\
\text { it's conler there's a lot of smoke. }\end{array}$ & $\begin{array}{l}\text { There are no health or } \\
\text { psychological benefits of } \\
\text { vaping for its users }\end{array}$ \\
\hline
\end{tabular}




\begin{tabular}{|c|c|c|}
\hline Question & Answer & Conclusion \\
\hline $\begin{array}{l}\text { Is there a difference } \\
\text { that you feel before } \\
\text { and after using } \\
\text { vape? }\end{array}$ & $\begin{array}{l}\text { if there's no difference, it's just superior to } \\
\text { that smell, if it's more economical it's not because } \\
\text { I'm double cigarettes, yes, vaping } \\
\text { is so wasteful, but sometimes some people } \\
\text { vape to stop smoking }\end{array}$ & $\begin{array}{l}\text { There is no difference } \\
\text { felt from before and after } \\
\text { using vape }\end{array}$ \\
\hline $\begin{array}{l}\text { Are you using } \\
\text { a liquid-vapor w } \\
\text { hich contained the } \\
\text { e-content } \\
\text { of nicotine? }\end{array}$ & $\begin{array}{l}\text { Yes, usually I use the } 0.8 \text {, it's just right for } \\
\text { me }\end{array}$ & $\begin{array}{l}\text { Informants usually use } \\
\text { vapes with nicotine } \\
\text { levels of } 0.8\end{array}$ \\
\hline $\begin{array}{l}\text { Is there } \\
\text { any impact that } \\
\text { you know if using } \\
\text { a vapor? If so, what } \\
\text { are the } \\
\text { impacts? }\end{array}$ & 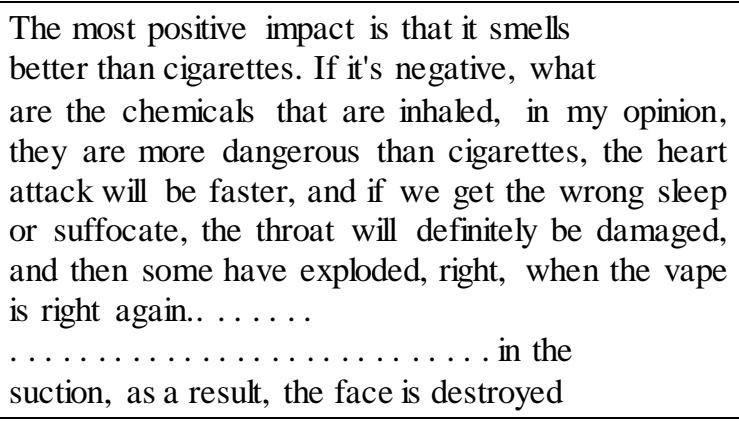 & $\begin{array}{l}\text { There is no positive } \\
\text { impact regarding health } \\
\text { or psychological. While some } \\
\text { negative impacts are known } \\
\text { by the informants }\end{array}$ \\
\hline $\begin{array}{l}\text { How does the } \\
\text { the way you avoid } \\
\text { the impact of using } \\
\text { a vapor? }\end{array}$ & $\begin{array}{l}\text { there is none because the disease is a test } \\
\text { from Allah SWT so I as his servant accept the } \\
\text { gift if it happens in the cave }\end{array}$ & $\begin{array}{l}\text { The resource person did } \\
\text { nothing to } \\
\text { prevent/reduce the } \\
\text { impact of vaping }\end{array}$ \\
\hline \multicolumn{3}{|c|}{ Attitude } \\
\hline $\begin{array}{l}\text { How } \\
\text { to view you as } \\
\text { to students of } \\
\text { Public } \\
\text { Health that uses } \\
\text { vapor? }\end{array}$ & $\begin{array}{l}\text { I might still use it, but I just } \\
\text { want to take off the opium for a while." } \\
\text { That's the concept of reducing it. After all, vaping } \\
\text { is talking about habits, so even if } \\
\text { you know the negative effects, it's still hard to stop }\end{array}$ & $\begin{array}{l}\text { Marcum believes that } \\
\text { once you get used to it, } \\
\text { it will be difficult to stop } \\
\text { even though you know the } \\
\text { negative impact }\end{array}$ \\
\hline
\end{tabular}

What do you

think about

"vapor is $\mathrm{s}$ a fe $\mathrm{r}$ than conventional cigarettes

the chemical substances that are inhaled in my opinion is more dangerous than cigarettes "?
Sources disagree that vaping is safer than conventional cigarettes

\section{How}

do think you about the "vapor one of the tools to quit it smoking"?
Have you ever heard that it's just not effective in the cave?
The informant stated that vaping did not help in smoking cessation therapy

\section{Personal References}

Has someone influenced you to use vape?

In your opinion, what is the most dominant factor to be the reason you use vapor? Tell! more stylish maybe like and want to smoke less

Yes, because the reason I vape was told by my ex first to smoke there are people who can influence narcism to use vape 


\begin{tabular}{|c|c|c|}
\hline Question & Answer & Conclusion \\
\hline \multicolumn{3}{|c|}{ Action } \\
\hline $\begin{array}{l}\text { Are you completely on } \\
\text { the vapor? }\end{array}$ & $\begin{array}{l}\text { it's not intense if you're bored like skipping } \\
6 \text { months at most after that vape again }\end{array}$ & $\begin{array}{l}\text { The resource person is } \\
\text { not a vape completely } \\
\text { because it is still } \\
\text { interspersed with } \\
\text { conventional cigarettes }\end{array}$ \\
\hline
\end{tabular}

When
did you first start using 2016
vape?

Resource persons using vape since 2016
Time and place to use vape every day ?
Everywhere, house, hangout, car

The time and place of

using vaping is tentative because there is no place prohibition on using vaping

Resource persons buy

\section{How}

many times do you buy vape liquid every month?

\section{1-2 times per month} month

Where usually do purchase the fluid vapor and the means

vape store like of vapor that is used?

What that be the For me, the main reason was that my ex the reason you use vapor? was told to do it, but now it's become a habit

The resource person buys vape liquid at the nearest vape store

The reason the interviewee uses vaping as a habit

\section{Table 3. Interview Matrix from Respondent 3}

\begin{tabular}{lll}
\hline Question & Answer & Conclusion \\
\hline & Knowledge & \\
\hline
\end{tabular}

What Do the benefits that you get when using a vapor? nice that you feel before and after using vape?
In my opinion, the benefits of vapor are only to reduce or stop smoking addiction caused by nicotine and improve blood vessel function from tobacco smokers, even though the vapor itself is not safe yet.

Previously I was a tobacco smoker and what I felt was that many diseases appeared, I switched to vapor, and what I feel after a few months of using vapor is safer than tobacco cigarettes to reduce or stop tobacco smoking addiction

There is a difference that is felt after using the vapor, it doesn't cause symptoms
Are you using a liquid-vapor $\mathrm{w}$ which contained th e-content of nicotine?
I've never used liquid or what is called liquid for vapors containing nicotine, because for example, if I use one with nicotine, it's the same thing.
The resource person has never used vapor or liquid 


\begin{tabular}{|c|c|c|}
\hline Question & Answer & Conclusion \\
\hline $\begin{array}{l}\text { Is there } \\
\text { any impact that } \\
\text { you know if using } \\
\text { a vapor? If so, what } \\
\text { are the } \\
\text { impacts? }\end{array}$ & $\begin{array}{l}\text { The impact of using vapor itself is not } \\
\text { much different from tobacco cigarettes, } \\
\text { such as causing lung disease, heart disease, cancer, } \\
\text { brain damage, and fetal disorders, that's all I know of } \\
\text { the impact }\end{array}$ & $\begin{array}{l}\text { The impact of using } \\
\text { vapor is not much } \\
\text { different from tobacco } \\
\text { cigarettes }\end{array}$ \\
\hline $\begin{array}{l}\text { How does the } \\
\text { the way you avoid the } \\
\text { impact of using } \\
\text { a vapor? }\end{array}$ & $\begin{array}{l}\text { For me, avoiding the effects of using } \\
\text { vaping by thinking about strong reasons to stop, } \\
\text { looking for support people to stop or } \\
\text { looking for a clean environment that doesn't use } \\
\text { vaping, reducing using vaping gradually, looking } \\
\text { for healthy activities or activities such as sports so } \\
\text { that they don't cause cravings. Evaporating at least } \\
\text { that's the only way I use so as not to be affected by } \\
\text { the vapor }\end{array}$ & $\begin{array}{l}\text { Looking for a positive } \\
\text { environment and distract } \\
\text { yourself with various } \\
\text { useful activities }\end{array}$ \\
\hline
\end{tabular}

How

to view you as

to students of

Public

Health that uses vapor?
I don't think it's good for public health children to use vapor because it doesn't set an example
Narsum thinks that it is not good because he is a healthy child
What do you think about "vapor is safer than conventional cigarettes "?

\section{Tobacco cigarettes are more dangerous} because they contain tar, tobacco nicotine because there is no danger of nicotine, tar, and carbon dioxide which make addiction like tobacco cigarettes, the vapor is safer because it has fewer chemicals.

\begin{tabular}{|c|c|c|}
\hline $\begin{array}{l}\text { How } \\
\text { do think you about } \\
\text { the "vapor one } \\
\text { of the tools to quit } \\
\text { smoking"? }\end{array}$ & $\begin{array}{l}\text { I switched to vapor or e-cigarettes to stop } \\
\text { smoking cigarettes, finally I managed to stop } \\
\text { smoking and switched to vapor and } \\
\text { what I feel after how many months of using } \\
\text { vapor }\end{array}$ & $\begin{array}{l}\text { The informant stated } \\
\text { that vaping helps in } \\
\text { smoking cessation } \\
\text { therapy }\end{array}$ \\
\hline \multicolumn{3}{|c|}{ Personal References } \\
\hline $\begin{array}{l}\text { Has someone } \\
\text { influenced you to use } \\
\text { vape? }\end{array}$ & There is not any & There is not any \\
\hline $\begin{array}{l}\text { In your opinion, } \\
\text { what is the most } \\
\text { dominant factor to } \\
\text { be the reason you } \\
\text { use } \\
\text { vapor? Tell! }\end{array}$ & Divert yourself from tobacco cigarettes & $\begin{array}{l}\text { To divert sources from } \\
\text { tobacco cigarettes }\end{array}$ \\
\hline \multicolumn{3}{|c|}{ Action } \\
\hline $\begin{array}{l}\text { Are you completely on } \\
\text { the vapor? }\end{array}$ & $\begin{array}{l}\text { Yes, occasionally smoke tobacco, but it's } \\
\text { rare }\end{array}$ & $\begin{array}{l}\text { The resource person is } \\
\text { not a vape completely } \\
\text { because it is rtill } \\
\text { interspersed }\end{array}$ \\
\hline $\begin{array}{l}\text { When } \\
\text { did you first start using } \\
\text { g vape? }\end{array}$ & Since 6 months ago & $\begin{array}{l}\text { The resource person has } \\
\text { been using vapor since } 6 \\
\text { months ago }\end{array}$ \\
\hline
\end{tabular}

Sources disagree that vaping is safer than conventional cigarettes 


\begin{tabular}{lll}
\hline \multicolumn{1}{c}{ Question } & \multicolumn{1}{c}{ Answer } & \multicolumn{1}{c}{ Conclusion } \\
\hline $\begin{array}{l}\text { Time and place } \\
\text { to use vape every day } \\
. ?\end{array}$ & Where to take it, at home, at the hangout & $\begin{array}{l}\text { The time and place of } \\
\text { using vaping is tentative } \\
\text { because there is no place } \\
\text { prohibition on using vaping }\end{array}$ \\
\hline $\begin{array}{l}\text { How } \\
\text { many times do you buy } \\
\text { vape liquid every month? }\end{array}$ & $\begin{array}{l}\text { Not necessarily depending on usage and } \\
\text { sometimes it runs out every 2 months }\end{array}$ & Uncertain \\
\hline $\begin{array}{l}\text { Where usually do } \\
\text { purchase the fluid } \\
\text { vapor and the means } \\
\begin{array}{l}\text { of vapor that } \\
\text { is used? }\end{array}\end{array}$ & vape store & vape store \\
\hline $\begin{array}{l}\text { What that be the } \\
\text { the reason you use vapor? }\end{array}$ & Let's not smoke tobacco anymore & In order not to smoke \\
\hline
\end{tabular}

Table 4. Interview Matrix from Respondent 4

\begin{tabular}{lll}
\hline \multicolumn{1}{c}{ Question } & \multicolumn{1}{c}{ Answer } & \multicolumn{1}{c}{ Conclusion } \\
\hline & & Knowledge \\
What Do the & feel the mouth becomes fragrant, there is \\
mouth activity, peat remover & $\begin{array}{l}\text { The informant felt that } \\
\text { the benefits of vapor } \\
\text { when using a vapor? }\end{array}$ & $\begin{array}{l}\text { where to make the mouth } \\
\text { smell better and relieve } \\
\end{array}$ \\
\hline
\end{tabular}

Is there a difference that you feel before and after using vape?

nothing for now, for the first time I felt coughing and choking
The resource person did not feel there was a difference between before and after using vapor

Are you using

a liquid-vapor w hich

contained th

Yes

The resource person

e-content uses a vapor whose liquid

of nicotine?

contains nicotine

\section{Is there}

any impact that

you know if using

a vapor? If so, w

hat are the

impact on lung health

Resource persons know

that vapor can cause

lung health problems

impacts?

How does the

the way you avoid the

impact of using a

don't use vape too often

Resource persons avoid vapor?

\begin{tabular}{|c|c|c|}
\hline \multicolumn{3}{|c|}{ Attitude } \\
\hline $\begin{array}{l}\text { How } \\
\text { to view you as }\end{array}$ & & $\begin{array}{l}\text { The informants have the } \\
\text { view that the vapor habit }\end{array}$ \\
\hline $\begin{array}{l}\text { to students of } \\
\text { Public }\end{array}$ & $\begin{array}{l}\text { go back to each other and deal with it } \\
\text { individually on health }\end{array}$ & $\begin{array}{ll}\text { depends on each } \\
\text { individual }\end{array}$ \\
\hline $\begin{array}{l}\text { Health that uses } \\
\text { vapor? }\end{array}$ & 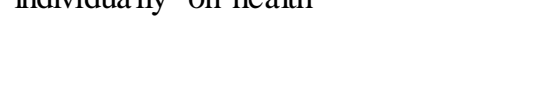 & $\begin{array}{l}\text { influenced by the } \\
\text { environment }\end{array}$ \\
\hline
\end{tabular}




\begin{tabular}{lll}
\hline \multicolumn{1}{c}{ Question } & \multicolumn{1}{c}{ Answer } & \multicolumn{1}{c}{ Conclusion } \\
\hline $\begin{array}{l}\text { What do you } \\
\text { think about } \\
\text { "vapor is safer } \\
\text { than conventional } \\
\text { cigarettes"? }\end{array}$ & $\begin{array}{l}\text { Yes, that's right, the Nik content in liquid } \\
\text { vape is only ml/bottle, while cigarettes are a stick }\end{array}$ & $\begin{array}{l}\text { interviewees feel that } \\
\text { vapor is safer } \\
\text { conventional cigarettes }\end{array}$ \\
$\begin{array}{l}\text { How than } \\
\text { do think you abo }\end{array}$ & Yes, that's right, because the mouth feels \\
$\begin{array}{l}\text { ut the "vapor one of } \\
\text { the tools to quit } \\
\text { smoking"? }\end{array}$ & bitter after using vape & $\begin{array}{l}\text { The informants agreed } \\
\text { that vapor is one of the } \\
\text { tools that can be used to stop } \\
\text { smoking }\end{array}$ \\
\hline $\begin{array}{l}\text { Has someone } \\
\text { influenced you to use } \\
\text { vape? }\end{array}$ & Plose friends and hangout friends & $\begin{array}{l}\text { Resource persons are } \\
\text { influenced by their friends so } \\
\text { they use vape }\end{array}$ \\
\hline
\end{tabular}

In your opinion, what is the most dominant factor to be the reason you use

environmental factors and friend factors, because it feels good after trying it
According to sources, the environment is the dominant factor in vaping behavior

vapor? Tell!

\section{Action}

Are you completely on Yes, it is true the vapor?

When
did you first start using 18 years old
vape?

Time and place to use vape every day ?
The resource person is completely vapor

The resource person has been using vapor since he was 18 years old 18
Resource persons use vapor in rooms, vape shops, and cafes
Resource persons fill in liquid every 1 month vape liquid every month?

Where usually do purchase the fluid vapor and the means of vapor that is used? room, vape shop, and cafe

a month
The resource person buys liquid at the nearest vape store

\begin{tabular}{|c|c|c|}
\hline $\begin{array}{l}\text { What that be the } \\
\text { the reason you use vapor? }\end{array}$ & feels good when sucked & $\begin{array}{l}\text { Resource persons feel } \\
\text { comfortable using vape }\end{array}$ \\
\hline
\end{tabular}

\section{CONCLUSIONS AND SUGGESTIONS}

E-cigarettes were first created in a modern way by a pharmacist from China in 2003 and patented in 2004 and then began to spread throughout the world in 2006-until now with various brands. The E-cigarette is a device that functions like a cigarette but does not use or burn tobacco leaves, but 
converts liquid into vapor which is inhaled by smokers into their lungs, electronic cigarettes generally contain nicotine, other chemicals, and flavors/flavors and are toxic/toxic. poison (P2PTM). The Ministry of Health of the Republic of Indonesia (2014) explained that Electronic Cigarettes (ECs) or Electronic Nicotine Delivery System (ENDS) are devices that function to convert chemical substances into vapor and flow them to the lungs, where these chemicals are a mixture of substances such as nicotine and alcohol. propylene glycol. Based on in-depth interviews with the informants, it was found that the informants had various reasons for using vapor, both for health reasons and for environmental reasons. All resource persons also argue that the dominant factor that makes a person use vapor is environmental factors. Meanwhile, when viewed from the behavior of all informants, they do not use vapor continuously but at certain times, even one of the informants still uses conventional cigarettes to be accompanied by vapor.

\section{REFERENCES}

Alawiyah, SS (2017) 'A description of the perception of e-cigarettes among e-cigarette users in the vaporizer community of Tangerang city.

Cleopatra, AB, Fitriangga, A., and Fahdi, FK (2018) 'FACTORS RELATED TO ELECTRIC CIGARETTE USE IN THE REGION OF BARAT PONTIANAK DISTRICT', 013, pp. 1-10.

Hasna, FNA El (2017) 'FACTORS RELATED TO ELECTRIC CIGARETTE USE IN BEGINNING $\begin{array}{llllll}\text { SMOKERS IN SMA CITY BEKASI', 5, } & \text { pp. }\end{array}$

Karuniawati, A. (2019) 'Factors Affecting the Use of E-Cigarettes (vape) in State Junior High School Students in Rambang District, Purbalingga Regency', Thesis of the Faculty of Education, State University of Semarang, pp. 29-30.

Lazuardi, AI (2017) 'Lifestyle of Vape Use', Anthropology Fisip Universitas Airlangga, pp. 1-10. Pratama,ferina nadya (2020) 'Digital Digital Repository Repository University of Jember Jember

Staphylococcus aureus Digital Digital Repository Repository University of Jember Jember University, Thesis.

Pratiwi, N. (2020) 'The relationship of knowledge and attitudes with the behavior of using ecigarettes (vape) in the vape user community in Medan City.

Puterikami, A. (2018) 'Motivation of the use of e-cigarettes in young adults in Jabodetabek'.

Vinet, L. and Zhedanov, A. (2011) 'A "missing" family of classical orthogonal polynomials, Journal of Physics A: Mathematical and Theoretical, 44(8), pp. 1689-1699. DOI: 10.1088/1751$8113 / 44 / 8 / 085201$

Yosua, D. (2018) 'Millennial Generation's Perception About the Use of E-Cigarettes (VAPE) in Medan Selayang District in 2018', pp. 1-129. 